\title{
GROUNDNUT POLICIES, GLOBAL TRADE DYNAMICS, AND THE IMPACT OF TRADE LIBERALIZATION
}

\author{
Ndiame Diop, John C. Beghin, and Mirvat Sewadeh
}

Since the mid-1990s all major groundnut-exporting countries have been gradually liberalizing their groundnut sectors, in part to fulfill their commitments under World Trade Organization (WTO) agreements. ${ }^{1}$ The results have been mixed, and trade in groundnut products remains heavily distorted. Both China and India have removed some import restrictions and allowed wider privatesector participation in importing groundnuts. However, tariffs on groundnut products remain very high in India and high in China. The large market size of both countries exacerbates these distortions and their effects on the world market.

In the United States the 2002 Farm Bill eliminated many unsustainable features of previous groundnut policies (such as the high support price and production quotas), but it introduced new distortions, such as countercyclical payments and the floor price mechanism. These policies subsidize U.S. groundnut exports when world prices are low, with the potential to depress world market prices.

Argentina still selectively subsidizes some processed groundnut products and exports and applies moderate export taxes on groundnuts. In
Sub-Saharan Africa heavy producer taxation has ended, and unilateral liberalization efforts are continuing, although significant protection of processing remains.

The current situation raises many questions about the future of the sector and the prospects for various players. How will multilateral groundnut trade liberalization affect the competitive positions of different players? Which countries are likely to gain and which are likely to lose? How will small Sub-Saharan African producers be affected?

\section{Groundnut Production}

Groundnuts are a valuable source of protein, fat, energy, and minerals, and they generate cash income to many poor farmers in the developing world, especially in Sub-Saharan Africa and Asia. In Senegal, for instance, 70 percent of the rural labor force is employed in groundnut production, which accounts for 60 percent of households' agricultural income. Groundnut production and processing represent about 2 percent of gross domestic product and 9 percent of exports in Senegal.

This chapter is an abbreviated version of Diop, Beghin, and Sewadeh (2004), which is reproduced on the CD-ROM. 
TABLE 12.1 Production, Use, and Export of Groundnuts, Average 1996-2001

\begin{tabular}{|c|c|c|c|c|c|c|c|}
\hline Country & $\begin{array}{c}\text { Area } \\
\text { Harvested } \\
(1,000 \text { ha })\end{array}$ & $\begin{array}{c}\text { Yield } \\
\text { (mt/ha) }\end{array}$ & $\begin{array}{l}\text { Production } \\
\text { (1,000 mt) }\end{array}$ & $\begin{array}{c}\text { Domestic } \\
\text { Use } \\
(1,000 \mathrm{mt})\end{array}$ & $\begin{array}{l}\text { Edible } \\
\text { Groundnuts } \\
(1,000 \mathrm{mt})\end{array}$ & $\begin{array}{l}\text { Crushed for } \\
\text { Oil and Cake } \\
(1,000 \mathrm{mt})\end{array}$ & $\begin{array}{c}\text { Net } \\
\text { Exports } \\
(1,000 \mathrm{mt})\end{array}$ \\
\hline World & 21,452 & 1.4 & 29,997 & 29,896 & 12,416 & 14,590 & 169 \\
\hline \multicolumn{8}{|c|}{ Main producers and exporters } \\
\hline China & 4,234 & 2.9 & 12,204 & 11,777 & 4,753 & 6,140 & 427 \\
\hline India & 7,902 & 0.9 & 7,176 & 7,082 & 534 & 5,581 & 94 \\
\hline United States & 569 & 3.0 & 1,701 & 1,428 & 978 & 280 & 220 \\
\hline Argentina & 280 & 1.5 & 403 & 191 & 21 & 155 & 213 \\
\hline \multicolumn{8}{|c|}{ Main producers in Africa } \\
\hline Nigeria & 1,187 & 1.1 & 1,340 & 1,340 & 636 & 427 & 0 \\
\hline Senegal & 690 & 1.1 & 722 & 730 & 317 & 304 & -6 \\
\hline South Africa & 98 & 1.7 & 161 & 123 & 72 & 32 & 33 \\
\hline Malawi & 117 & 0.9 & 103 & 101 & 78 & 18 & 2 \\
\hline Gambia, The & 89 & 1.0 & 95 & 80 & 26 & 54 & 15 \\
\hline \multicolumn{8}{|l|}{ Main importers } \\
\hline European Union & 1 & 1.0 & 1 & 454 & 433 & 17 & -449 \\
\hline Canada & 0 & 0.0 & 0 & 115 & 115 & 0 & -115 \\
\hline Japan & 12 & 2.3 & 28 & 129 & 121 & 2 & -103 \\
\hline Korea, Rep. of & 7 & 2.2 & 15 & 30 & 30 & 0 & -15 \\
\hline
\end{tabular}

Note: The difference between production plus net exports and domestic utilization reflects stock variation and feed and seed use. Ending stocks are negligible for all countries except the United States, which had ending stocks of 28 percent of total production during 1996-2001.

Source: U.S. Department of Agriculture.

China is the world's largest groundnut producer, with 40 percent of world production in 2001. India accounts for 23 percent of worldwide production, a group of Sub-Saharan African countries produces 8.4 percent, and the United States produces 5.6 percent (table 12.1). Malawi, Nigeria, South Africa, and the United States produce shelled groundnuts, which are used as seed, consumed raw, or consumed after having been transformed into prepared (roasted, salted, flavored) groundnuts or groundnut butter or paste. In contrast, Argentina, China, India, and Senegal devote more than 60 percent of their production to crushing groundnuts for oil and meal. $^{2}$

Groundnut production conditions vary considerably across countries, reflecting differences in technological development, access to modern inputs and irrigation, and farm management practices. Yields are highest in the United States and China and lowest in Sub-Saharan Africa (except South Africa) and India. The low yields in Africa and India are the result of limited use of modern inputs, including high-yielding seed varieties, and heavy dependence on rainfall.
Driven by tremendous growth in China, global shelled production grew 34 percent between 1981-85 and 1996-2000. Growth has been uneven across countries (figure A12.1 on the CD-Rom). China doubled its production between 1992 and 2000 by increasing its use of high-yielding varieties and agricultural inputs, including fertilizers, pesticides, mechanization, and irrigation (Colby and others 1992). In India production exhibited significant fluctuations, increasing between 1987 and 1998 before returning to the production levels of the 1970s (about 6 million tons). Production in SubSaharan Africa picked up in the early 1990s, after a long period of decline. Production has been stable since the early 1970s in the United States, which produces about 2 million tons a year, and in Argentina, which produces 300,000 tons.

The economic costs of groundnut production vary significantly across countries. In 1993 the average cost per acre was $\$ 694$ in the United States, more than three times the average cost in China of $\$ 164$ per acre (table 12.2). The higher economic costs per acre for U.S. groundnuts were attributed chiefly to production quota rent, land value, and 


\section{TABLE 12.2 Costs of and Revenues from Groundnuts in China and the United States} (US\$ per acre)

\begin{tabular}{|l|c|c|c|c|} 
& \multicolumn{2}{|c|}{1992} & \multicolumn{2}{c}{1993} \\
\hline Item & United States & China & United States & China \\
\hline Variable costs & & & & \\
Seed & 70.32 & 43.83 & 71.18 & 45.96 \\
Fertilizer & 43.27 & 25.03 & 42.40 & 26.13 \\
Chemicals & 89.70 & 3.40 & 92.57 & 3.68 \\
Labor & 89.14 & 71.51 & 86.17 & 75.86 \\
Other expenses & 212.84 & 41.43 & 188.54 & 12.82 \\
Subtotal & 505.27 & 185.20 & 480.86 & 164.45 \\
Fixed costs & & & & \\
Land value & 92.58 & - & 97.77 & - \\
Quota rent & 113.38 & - & 115.40 & - \\
Total costs & 711.23 & 185.20 & 694.03 & 164.45 \\
Yield (pounds per acre) & 2576 & 2520 & 1940 & 2135 \\
Revenue (producer price times yield) & 753.66 & 323.69 & 570.58 & 280.83 \\
\end{tabular}

- Not available.

Note: More recent data are not available.

Source: Chen and others 1997.

the costs of using and maintaining farm equipment, fuel, electricity, repair, and capital replacement. Quota rent and land value are not costs for farmers in China, since there is no production quota and land is considered public property, belonging to local communities organized in groups of 30-40 households (Chen and others 1997). ${ }^{3}$ Net returns for China and the United States are not significantly different if quota rent (irrelevant since the 2002 Farm Bill) is excluded from U.S. production costs. The U.S. cost disadvantage is, however, compensated for by higher producer prices brought about by the groundnut program and the higher quality of U.S. groundnuts. The elimination of quota production (and thus quota rent) in the 2002 Farm Bill reduces U.S. production costs. This development, as well as the high quality of U.S. groundnuts, which earn a high price premium in international markets, may well maintain U.S. competitiveness with China. ${ }^{4}$

\section{Global Trade in Groundnuts}

Domestic consumption of groundnuts is high, and only 5 percent of world production is sold in international markets. Of the three major groundnut products traded internationally (edible groundnuts, groundnut oil, and groundnut meal), edible groundnuts are the most traded, with a volume of 1.2 million tons in 2001; trade in groundnut oil was 250,000 tons (table 12.3). The global export of edible groundnuts has increased 2.2 percent a year since the early 1980s, while exports of groundnut oil declined 1 percent and meal exports fell 2.5 percent, despite growing global consumption of both products.

China is the world's largest exporter of edible groundnuts, accounting for 32 percent of world exports. The United States is the second-largest exporter, with 19 percent of the world market, followed by Argentina, at 10.5 percent. Sub-Saharan Africa (The Gambia, Malawi, Nigeria, Senegal, South Africa, and Sudan) has lost market share in international edible groundnut markets and accounts for only 5 percent of world trade. Senegal is the world's largest supplier of groundnut oil, but this market has declined as other vegetable oils are increasingly used as substitutes.

The European Union (EU) is the single largest groundnut market, accounting for 43 percent of world imports. The total value of net groundnut imports in the European Union was just below $\$ 500$ million a year in 1996-2000. Canada, with 9 percent of world imports, is the second-largest market, followed by Japan, which imports 8.2 percent of world groundnuts. 
TABLE 12.3 Value of Net Exports, by Groundnut Product, 1996-2000 (US\$ millions)

\begin{tabular}{|l|r|r|r|r|}
\hline Country & Edible Groundnut & Groundnut Oil & Prepared Groundnut & Total \\
\hline EU-15 & -378.47 & -115.12 & -4.54 & -498.13 \\
Japan & -44.00 & -1.85 & -71.46 & -117.31 \\
Canada & -76.67 & -1.19 & -3.31 & -81.18 \\
Korea, Rep. of & -4.55 & 0.01 & -14.31 & -18.86 \\
Malawi & 0.77 & 0.00 & 0.00 & 0.77 \\
Nigeria & -3.29 & 4.64 & 0.00 & 1.35 \\
Gambia, The & 4.49 & 1.09 & 0.05 & 5.63 \\
South Africa & 16.01 & 4.68 & 0.27 & 20.95 \\
Senegal & 3.34 & 48.99 & 0.60 & 52.92 \\
India & 86.85 & -0.13 & 7.27 & 93.99 \\
United States & 126.43 & -12.77 & 28.26 & 141.92 \\
Argentina & 160.98 & 51.52 & 25.82 & 238.32 \\
China & 193.79 & 2.82 & 111.06 & 307.68 \\
\hline
\end{tabular}

Note: Prepared groundnuts are roasted, salted, or flavored groundnuts. Peanut butter is not included. Source: FAOSTAT.

Consistent with growth in world consumption, exports of raw edible groundnuts and prepared groundnuts have expanded rapidly since the mid1980s (figures 12.1a-12.1d). Exports of edible groundnuts increased 8 percent in the 1990s, after a dramatic increase of more than 20 percent during the 1980s. The pattern of growth in prepared groundnut exports broadly mirrors that of edible groundnuts, signaling the highly integrated nature of these markets (figure 12.1c).

China has been the major beneficiary of this expansion (figure 12.1b). From barely 1 percent in 1976, its global market share in exports of edible groundnuts rose to 32 percent in 2001. During the same period, the U.S. market share dropped from 32 percent to 19 percent. The emergence of China as a leading exporter in the prepared groundnut market is even more impressive (figure 12.1d).

While the international edible groundnut market has become more concentrated (with 61 percent of exports controlled by China, the United States, and Argentina in 2001), the market for prepared groundnuts has become more fragmented. Concentration in the edible groundnut market partially reflects the significant decrease in SubSaharan Africa's share of prepared groundnuts, from 17 percent in 1976 to 5 percent in 2001 . Africa's market countries (including The Gambia, Malawi, and Nigeria) enter the edible groundnut export market intermittently, depending on their crop quality and world market demand.
Figures 12.1e and 12.1f show the trends in exports and market shares of groundnut oil. Many countries, including Brazil and China, have exited the groundnut oil market since 1976 to focus on edible groundnuts and other vegetable oils. Other countries, such as the United States, have chosen to enter the market only when the quality of groundnuts harvested is too low for the nuts to be sold in the edible groundnut market. Senegal and Argentina remain the world's leading exporters of groundnut oil. The market has become significantly fragmented, however. Argentina, Brazil, Senegal, and the United States jointly supplied just 52 percent of total exports in 2001, down from 85 percent in 1976.

The decline in African countries' shares in global groundnut markets has significantly reduced the contribution of groundnut products to the export earnings of many Sub-Saharan African countries. The importance of groundnut products as a source of export earnings has declined dramatically in Malawi, Senegal, and South Africa since the early 1980s (table 12.4). The importance of groundnut products increased significantly only in The Gambia, where they accounted for 84 percent of total merchandise exports in 2000-02.

The volume of raw edible groundnuts exported decreased significantly in Malawi, Nigeria, and South Africa and stagnated in The Gambia and Senegal (table 12.4). As a result of declining and almost stagnant volumes, export earnings for 


\section{FIGURE 12.1 Global Groundnut Consumption, Exports, and Market Shares}

(a) Global Exports and Consumption of Raw Edible Groundnuts, 1976-2002

(1,000 metric tons)

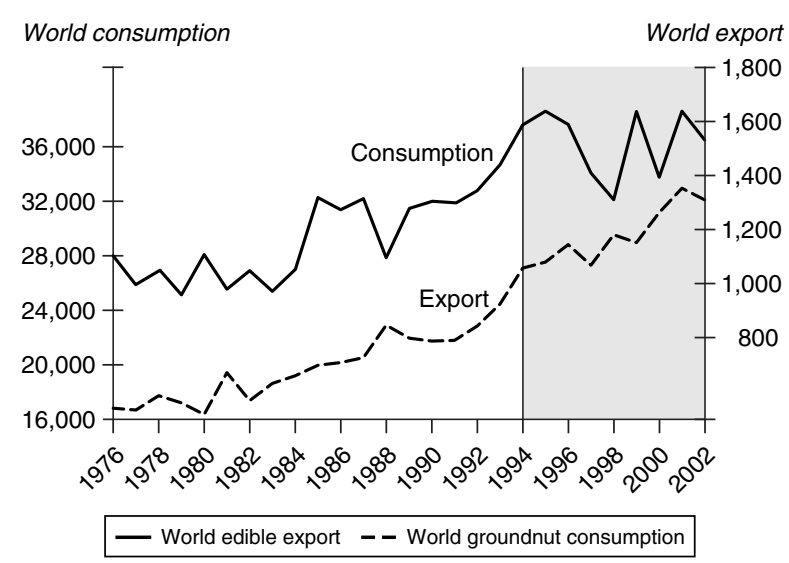

(c) Global Exports of Prepared Groundnuts, 1976-2002

(tons)

Metric tons

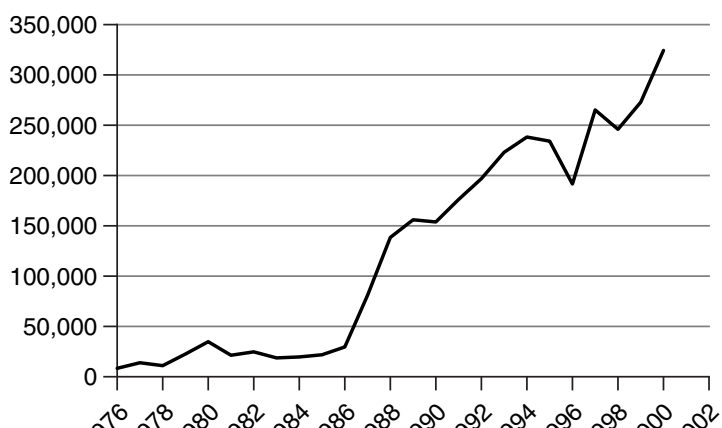

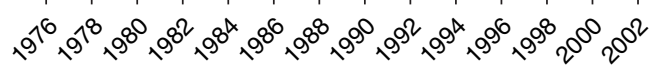

(e) Global Exports of Groundnut Oil

(1,000 metric tons)

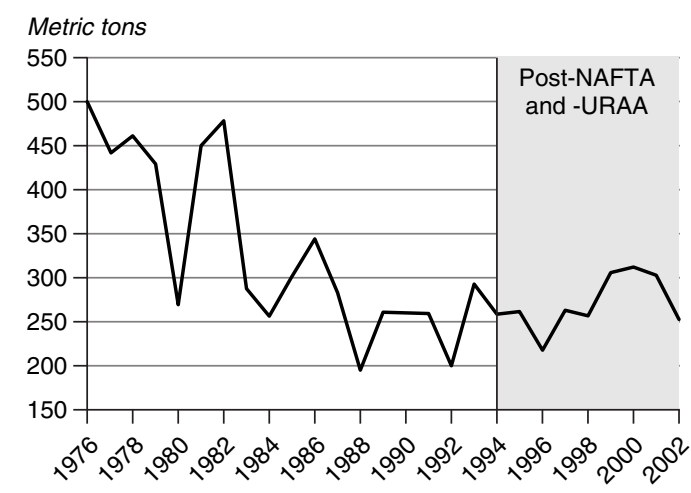

(b) Market Shares of Global Raw Edible Groundnut Exports, 1976-2002 (percent)

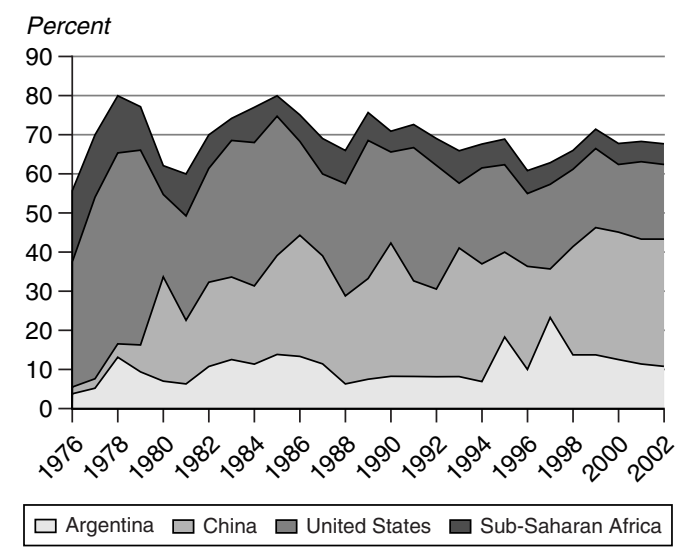

(d) Market Shares of Global Prepared Groundnut Exports, 1976-2002 (percent)

Percent

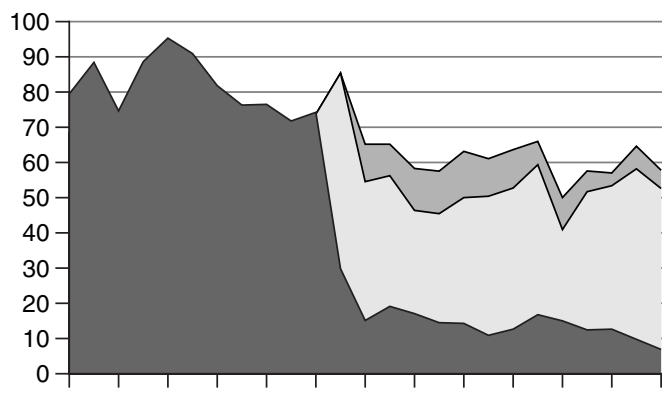

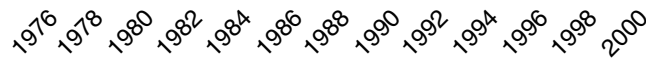
$\square$ United States $\square$ China $\square$ Netherlands

(f) Market Shares of Global Groundnut Oil Exports (percent)

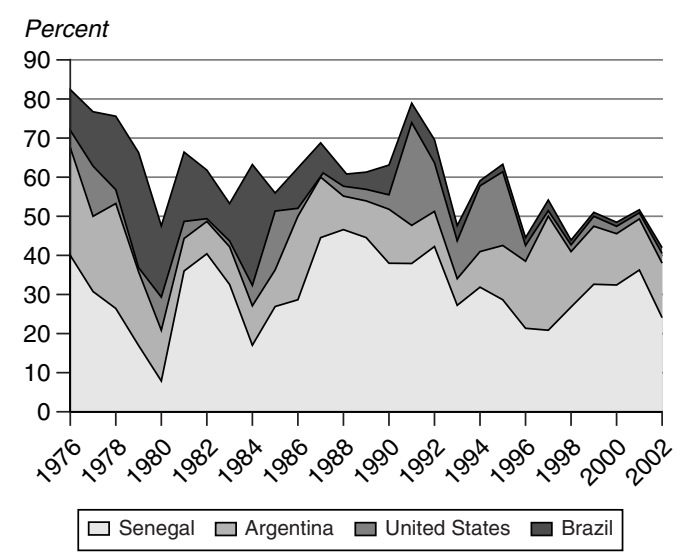


TABLE 12.4 Share of Groundnut Products in Total Merchandise Exports

\begin{tabular}{|c|c|r|r|r|r|r|}
\hline Item & Period & The Gambia & Malawi & Nigeria & Senegal & South Africa \\
\hline Shelled groundnut exports & & & & & & \\
Volume (metric tons) & $1980-82$ & 27,333 & 14,867 & 1,026 & 2,725 & 41,333 \\
& $2000-02$ & 27,939 & 662 & 412 & 2,915 & 34,830 \\
\hline Value (US\$ thousands) & $1980-82$ & 11,743 & 12,333 & 400 & 2,145 & 29,730 \\
& $2000-02$ & 5,763 & 436 & 204 & 1,371 & 22,875 \\
\hline Groundnut oil exports & & & & & & \\
Volume (metric tons) & $1980-82$ & 7,651 & 0 & 0 & 82,693 & 22,667 \\
& $2000-02$ & 8,633 & 0 & 1,287 & 98,879 & 1,519 \\
Value (US\$ thousands) & $1980-82$ & 6,400 & 0 & 0 & 60,285 & 14,071 \\
& $2000-02$ & 6,333 & 0 & 797 & 63,007 & 1,053 \\
Share of groundnuts in & $1980-82$ & 59.62 & 4.65 & 0.003 & 16.17 & 0.21 \\
total exports (percent) & $2000-02$ & 84.64 & 0.10 & 0.006 & 8.16 & 0.08 \\
& & & & & & \\
\end{tabular}

Note: The share of groundnuts in total goods exports includes exports of groundnut meal.

Source: Production and groundnut exports data, FAOSTAT; total goods exports, World Bank.

shelled groundnuts dwindled. The extent of the decline suggests that unit values also decreased in The Gambia, Malawi, and Senegal.

\section{International Prices of Groundnuts}

Prices declined sharply in The Gambia and, to a lesser degree, in Senegal, while prices in South Africa remained higher (figure 12.2). The discount on groundnuts of Gambian and Senegalese origin reflects both their lower quality and stricter EU quality and technical standards. The European Union has become more demanding, from both a public health and a technical standpoint (size, uniformity). ${ }^{5}$ Nigeria and Senegal increased the volume and value of their exports of groundnut oil, while South Africa exited the groundnut oil market.

International prices of edible groundnuts and groundnut oil in the Rotterdam market (the reference for groundnut trade) have exhibited two distinct patterns since 1970 (figure 12.3). During 1970-81 the prices of both products were increasing. Tests show no cointegration between edible groundnut and groundnut oil during this period (tables A12.1-A12.3 on the CD-ROM). Prices were high, and the world market was dominated by the United States, which supplied 45 percent of exports, and Sub-Saharan Africa, which supplied 18 percent. China exported no edible groundnuts or groundnut oil.
In sharp contrast with the 1970s, groundnut prices over the past 20 years have been stable, constantly reverting to their mean values following shocks (tables A12.4 and A12.5 on the CD-ROM). Two subperiods can be distinguished. Before 1994 prices of groundnuts displayed a higher level of volatility. The coefficient of variation of prices stood at 20 percent between 1980 and 1994, almost three times the 7 percent level witnessed between 1995 and 2001.

What are the main causes of this price variability? Is the change in price variability permanent? Revoredo and Fletcher (2002b) analyze both production instability (originating in exporting countries) and consumption instability (originating in importing countries). They find that the steady expansion of Chinese exports, which are negatively correlated with exports from Argentina and United States, was a stabilizing force in the second half of the 1990s. This stabilization occurred despite the fact that Argentina, India, and South Africa now transmit a higher proportion of their supply shocks to the world market.

Substitution between Chinese and U.S. groundnuts appears to have increased in recent years, although detailed data on substitution in world markets are not available.

In the groundnut oil market, the influence of Senegal on world prices remains significant. Senegal exported about 100,000 metric tons of groundnut 


\section{FIGURE 12.2 Unit Price of Raw Edible Groundnuts Produced in The Gambia, Senegal, and South Africa \\ (US\$ per ton)}

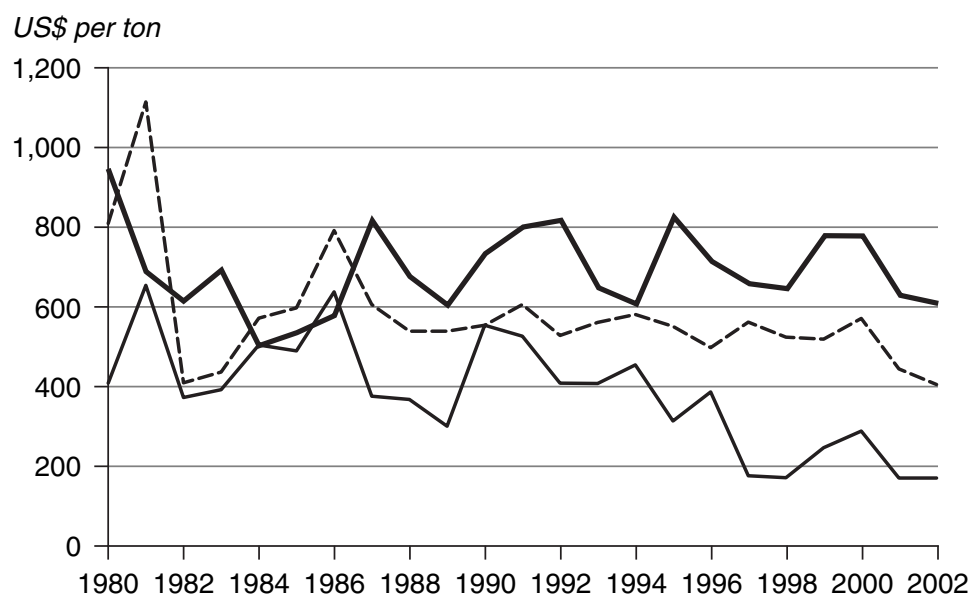

- The Gambia --- Senegal - South Africa

Source: FAOSTAT.

FIGURE 12.3 Rotterdam Prices of Groundnuts, 1970-2000 (cif, US\$ per metric ton)

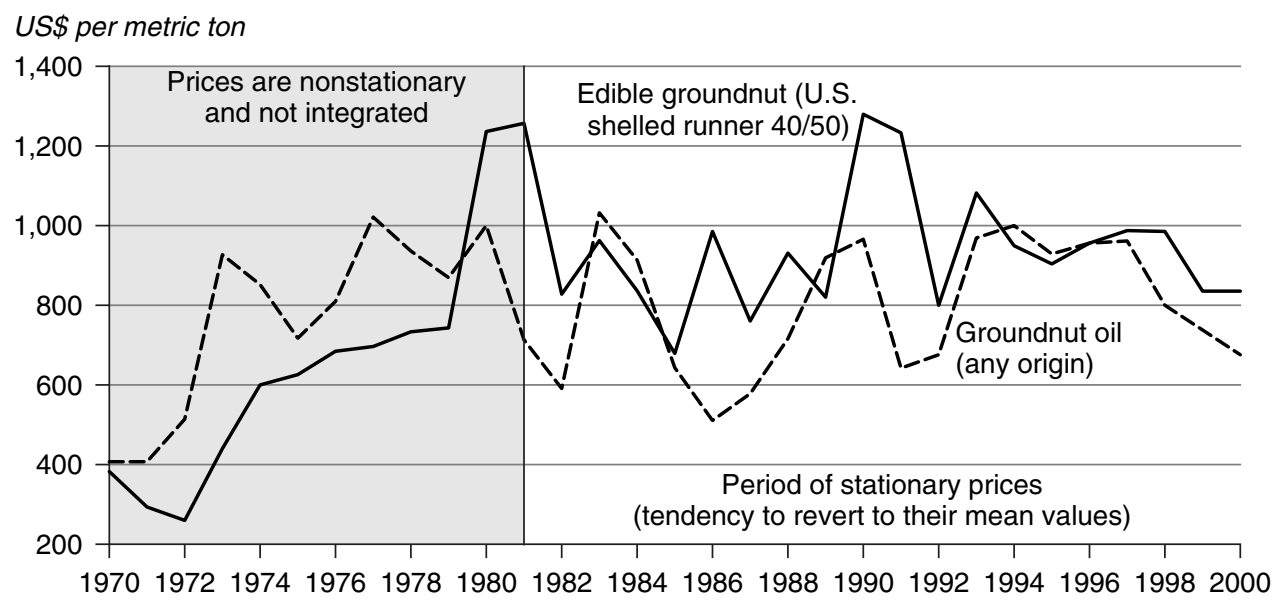

Source: Oil World, various issues.

oil in 2000-01, representing one-third of world exports and more than 60 percent of demand from the European Union, Senegal's main export market. While 2000-01 was an exceptional production year, econometric tests strongly indicate that variations in Senegal's exports were transmitted into the variability in international prices and that the reverse was not true.

Groundnut oil markets are broadly integrated with markets for other vegetable oils (soy oil, rapeseed oil, palm oil, and sunflower oil). Integration seems to be much stronger for other oilseeds than for groundnuts, however.

\section{Domestic Groundnut Policies of Major Countries in World Markets}

Domestic producer support and taxation and trade policies determine excess supply and trade flows. It is important to examine these policies-in Argentina, China, India, Sub-Saharan Africa, and the United States - in some detail to anticipate the 
potential implications of policy changes on the distribution of gains and losses across countries.

\section{Groundnut Policies in the United States}

Groundnut products are a minor sector nationally, but they are a key component of agriculture and rural development in the southern part of the United States. Based on the U.S. Department of Agriculture (USDA) Census of Agriculture, many counties in the South derive 50-70 percent of their agricultural income from groundnuts. Shelling is performed locally, as are many groundnut product manufacturing activities (Fletcher 2001). Groundnut policies have played a major role in maintaining rural income in these counties.

The foundation of U.S. groundnut policy is the U.S. peanut program, which traces its roots to the 1930s. Until the enactment of the 2002 Farm Bill, the pillars of the system were production regulation through quotas, high producer support prices, and import control. The groundnut support program existed as a two-tier price support program. The support price for edible groundnuts was $\$ 610$ per short ton paid for production under quota. Other groundnuts ("additionals"), which could be either exported at world prices or sold to the domestic crushed groundnut industry, were eligible for a lower support price (\$132 in 2001). The quota farm-gate price tended to be higher than the prevailing export prices (table 12.5).

The average annual aggregate measure of support for U.S. groundnuts was estimated at \$330 million during 2000-01, \$31 million more than in 1996-2001. The average cost of aggregate support in 1996-01 stood at \$206 per metric ton of groundnuts produced in the United States (table 12.6).
The 2002 Farm Bill eliminated groundnut production quotas (with a quota buyout), converted the price support program to a system of direct and countercyclical payments, and set a price floor with a production subsidy (nonrecourse loans, with marketing loan provisions). The key features of the new program include the following:

- All current groundnut producers have equal access to a marketing loan program under which producers can pledge their crops as collateral to obtain a marketing loan rate equal to $\$ 355$ per short ton. Producers may repay the loan at a rate that is the lesser of the USDA-set repayment rate plus interest or the marketing loan rate plus interest, or they can forfeit the loan.

- For producers with a history of groundnut production, a new direct and fixed payment of \$36 per short ton is available. Historic producers are those who were engaged in groundnut production between 1998 and 2001. Eligible production equals the product of average yields in the base period and 85 percent of base-period acres. These so-called decoupled payments are made regardless of current prices or the actual crop planted, as long as the farm remains in approved agricultural uses.

- Producers with a history of groundnut production are also eligible for a new countercyclical payment when market prices are below an established target price of $\$ 495$ per short ton minus the $\$ 36$ per ton direct payment. The payment rate is the difference between the target price (\$495 per short ton) minus the direct fixed payment ( $\$ 36$ per ton) and the higher of the 12month national average market price for the marketing year for groundnuts or the marketing

TABLE 12.5 U.S. Producer Support Prices for Groundnuts, 1993-94 to 1998-99 (US\$ per pound)

\begin{tabular}{|l|c|c|c|c|c|c|}
\hline Item & $1993-94$ & $1994-95$ & $1995-96$ & $1996-97$ & $1997-98$ & $1998-99$ \\
\hline Quota price & 0.388 & 0.339 & 0.339 & 0.305 & 0.305 & 0.305 \\
\hline "Additional" price & 0.660 & 0.660 & 0.660 & 0.660 & 0.660 & 0.660 \\
Average farm price & 0.304 & 0.289 & 0.293 & 0.281 & 0.283 & 0.280 \\
CCC $^{\text {a export price }}$ & 0.200 & 0.200 & 0.200 & 0.200 & 0.200 & 0.200 \\
Export unit value & 0.330 & 0.286 & 0.292 & 0.322 & 0.327 & 0.328 \\
Rotterdam cif price & 0.371 & 0.292 & 0.336 & 0.316 & 0.360 & 0.290 \\
\hline
\end{tabular}

a. Commodity Credit Corporation.

Source: Skinner 1999. 
TABLE 12.6 U.S. Aggregate Support to Groundnuts, 1986-88 to 2000-01

\begin{tabular}{|l|c|c|}
\hline Period & $\begin{array}{c}\text { Aggregate Measure of Support } \\
\text { (millions of US\$) }\end{array}$ & $\begin{array}{c}\text { Aggregate Measure of Support per } \\
\text { Metric Ton of U.S. Production (US\$) }\end{array}$ \\
\hline $1986-88$ & 347.2 & 203.3 \\
$1995-96$ & 414.6 & 264.1 \\
$1996-97$ & 299.0 & 180.0 \\
$1997-98$ & 305.8 & 190.5 \\
$1999-2000$ & 300.0 & 172.7 \\
$2000-01$ & 330.0 & 222.8 \\
\hline
\end{tabular}

Source: Skinner 1999; Hart and Babcock 2002 for 2000-01 aggregate measure of support; USDA database for production data.

TABLE 12.7 U.S. Edible Groundnut Tariff Rate Quota Allocation, 1995-2008 (metric tons)

\begin{tabular}{|l|c|c|c|c|}
\hline Year & $\begin{array}{c}\text { Argentina } \\
\text { Uruguay Round } \\
\text { Tariff Rate Quota }\end{array}$ & $\begin{array}{c}\text { Mexico } \\
\text { NAFTA Tariff } \\
\text { Rate Quota }\end{array}$ & $\begin{array}{c}\text { Other } \\
\text { Uruguay Round } \\
\text { Tariff Rate Quota }\end{array}$ & $\begin{array}{c}\text { Total } \\
\text { NAFTA + Uruguay } \\
\text { Round }\end{array}$ \\
\hline 1995 & 26,341 & 3,478 & 4,052 & 33,871 \\
1996 & 29,853 & 3,582 & 5,043 & 38,478 \\
1997 & 33,364 & 3,690 & 6,034 & 43,088 \\
1998 & 36,877 & 3,801 & 7,024 & 47,702 \\
1999 & 40,388 & 3,915 & 8,015 & 52,318 \\
2000 & 43,901 & 4,032 & 9,005 & 56,938 \\
2001 & 43,901 & 4,153 & 9,005 & 57,059 \\
2002 & 43,901 & 4,278 & 9,005 & 57,184 \\
$2003-07$ & 43,901 & 4,278 & 9,005 & - \\
2008 & 43,901 & unrestricted & 9,005 & - \\
& & & & \\
\hline
\end{tabular}

- Not available.

Source: USDA.

assistance loan rate (\$355 per short ton). The total countercyclical payment to each eligible producer is calculated as the product of the payment acres ( 85 percent of base acres), the baseyear average yield, and the payment rate.

- Owners of groundnut quotas under the previous legislation receive compensation payments for the loss of quota asset value. Payments may be made in five annual installments of $\$ 220$ per short ton during fiscal years 2002-06, or the quota owner may opt to take the outstanding payment due in a lump sum. These payments are based on quota owners' 2001 quota, as long as they owned a farm eligible for the groundnut quota (Wescott, Young, and Price 2002).
Beginning in 1994, under the Uruguay Round and NAFTA (North American Free Trade Agreement), the United States gradually increased the quantities of groundnut imports through a tariff rate quota system. For edible groundnuts the total tariff rate quota in 2001 was 57,059 metric tons, or 4 percent of domestic consumption, allocated first to historical importers and then on a first-come, first-served basis (table 12.7). In-quota tariffs for edible and prepared groundnuts range between $\$ .066$ and $\$ .0935$ per kilogram. Out-of-quota tariffs are very high (131.8-163.0 percent under the Uruguay Round; table 12.8). ${ }^{6}$

The phase-out of groundnut trade barriers under NAFTA and the Uruguay Round is limited in 
Global Agricultural Trade and Developing Countries

TABLE 12.8 U.S. Over-Quota Tariffs, 1994-2008 (percent)

\begin{tabular}{|c|c|c|} 
Year & $\begin{array}{c}\text { NAFTA } \\
\text { Edible and Prepared Groundnuts }\end{array}$ & $\begin{array}{c}\text { Uruguay Round } \\
\text { Prepared Groundnuts and } \\
\text { Peanut Butter }\end{array}$ \\
\hline Base $^{\mathrm{a}}$ & 123.1 & 155.0 \\
1994 & 120.0 & - \\
1995 & 116.9 & 151.1 \\
1996 & 113.9 & 147.3 \\
1997 & 110.8 & 143.4 \\
1998 & 107.7 & 139.5 \\
1999 & 104.6 & 135.7 \\
2000 & 93.0 & 131.8 \\
2001 & 81.4 & 131.8 \\
2002 & 69.8 & 131.8 \\
2008 & 0.0 & - \\
\end{tabular}

a. Note: This indicates the base tariff levels from which the agreed cuts will be made.

- Not available.

Note: Prepared groundnuts are roasted, salted, or flavored groundnuts.

Source: USDA.

\section{TABLE 12.9 U.S. Imports of Edible Groundnuts}

\begin{tabular}{|c|c|c|c|c|c|c|c|}
\hline \multirow[b]{2}{*}{ Year } & \multicolumn{2}{|c|}{ Argentina } & \multicolumn{2}{|c|}{ Mexico } & \multirow{2}{*}{$\begin{array}{c}\text { Total } \\
\text { Imports }\end{array}$} & \multirow{2}{*}{$\begin{array}{l}\text { Total } \\
\text { Quota }\end{array}$} & \multirow{2}{*}{$\begin{array}{c}\text { Over-the- } \\
\text { Quota } \\
\text { Imports }\end{array}$} \\
\hline & Imports & Quota & Imports & Quota & & & \\
\hline 1996 & 38,270 & 29,853 & 4,710 & 3,583 & 57,000 & 38,478 & 18,522 \\
\hline 1997 & 40,622 & 33,365 & 6,148 & 3,690 & 64,000 & 43,088 & 20,912 \\
\hline 1998 & 34,465 & 36,875 & 4,834 & 3,801 & 70,000 & 47,702 & 22,298 \\
\hline 1999 & 39,494 & 40,388 & 4,916 & 3,915 & 82,000 & 52,318 & 29,682 \\
\hline 2000 & 72,230 & 43,901 & 4,864 & 4,032 & 97,000 & 56,938 & 40,062 \\
\hline 2001 & 37,557 & 43,901 & 3,611 & 4,153 & 81,000 & 57,059 & 23,941 \\
\hline 2002 & 29,927 & 43,901 & 4,406 & 4,278 & 46,795 & 57,184 & Not filled \\
\hline 2003 & 4,692 & 43,901 & 292 & 4,278 & 5,698 & 57,184 & Not filled \\
\hline
\end{tabular}

Source: USDA.

scope, but it continues to have a dramatic impact on U.S. imports. Edible groundnut imports by the United States-which were almost zero before 1994-have increased dramatically (table 12.9). Argentina's average fill rate was 87 percent and Mexico's, 77 percent, but out-of-quota imports were quite important, averaging 25,000 metric tons annually during 1996-2001. Edible groundnut imports represented 6 percent of U.S. groundnut consumption in 2001.

The initial impacts of the 2002 Farm Bill are also reflected in the collapse of imports in 2003 (see table 12.9). The elimination of production quotas decreased the price paid by U.S. processors, increasing domestic consumption of groundnuts (figure 12.4). It also removed the incentive to import edible groundnuts (Fletcher and Revoredo 2003; Revoredo and Fletcher 2002a).

\section{Groundnut Policies in Argentina, China, and India}

Since the mid-1990s Argentina, China, and India have gradually reduced potentially market-distorting direct government intervention in the production and marketing of groundnut products (table 12.10). 
FIGURE 12.4 U.S. Domestic Groundnut Prices, 1993-2003 (US\$ per metric ton)

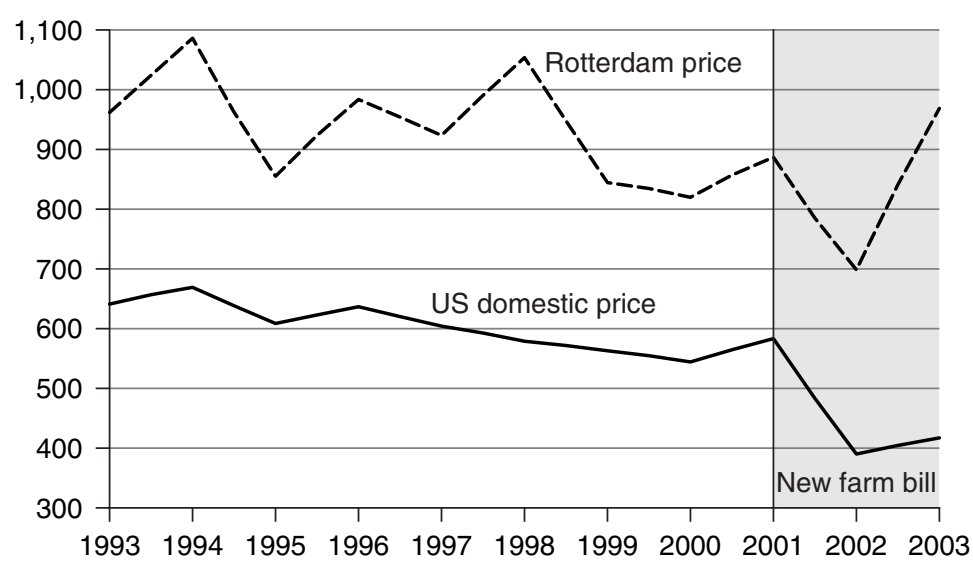

Source: USDA.

TABLE 12.10 Groundnut Trade Policy Distortions in Argentina, China, and India (percent)

\begin{tabular}{|c|c|c|}
\hline Country Product & Description & $1999 / 2002$ \\
\hline \multicolumn{3}{|l|}{ Argentina } \\
\hline Edible groundnuts & Import tariff & 5 \\
\hline Groundnut oil & Import tariff & 13 \\
\hline Groundnut meal & Import tariff & 8 \\
\hline Edible groundnuts & Export tax & 3.5 \\
\hline Groundnut meal & Export rebate & 3.2 \\
\hline Groundnut oil (refined) & Export rebate & 2.3 \\
\hline \multicolumn{3}{|l|}{ China } \\
\hline Raw edible groundnuts & Import tariff & 15 \\
\hline Processed edible groundnuts & Import tariff & 30 \\
\hline Groundnut oil & Import tariff & 10 \\
\hline Groundnut meal & Import tariff & 5 \\
\hline VAT on edible groundnuts and groundnut oil & VAT & 17 \\
\hline \multicolumn{3}{|l|}{ India } \\
\hline Edible groundnuts & Import tariff & 45 \\
\hline Groundnut oil & Import tariff & 35 \\
\hline Groundnut meal & Import tariff & 45 \\
\hline
\end{tabular}

Note: India raised its tariff on oil to 65 percent in 2002 and 85 percent in 2003. Raw edible groundnuts are raw, not roasted or cooked, in shell or shelled groundnuts. Processed groundnuts are bleached, preserved, or otherwise prepared groundnuts, including roasted, salted, and groundnut butter.

Source: WTO; WITS; USDA GAIN Report.

Argentina. Argentina's groundnut trade policy contrasts sharply with that of India and China, as almost all the distortions are associated with exports, which are subject to a 3.5 percent tax on raw groundnuts. With the peso devaluation of 2001, export tax retention on groundnut exports increased to 20 percent. This export tax may countervail the positive signal sent to groundnut exporters through the peso devaluation. Argentina maintains import tariffs on groundnut products, which exhibit some escalation (5 percent on edible groundnuts, 8 percent on groundnut meal, and 
13 percent on groundnut oil). These tariffs are often redundant, since the country is a net exporter of groundnut products.

China. Like India, China liberalized groundnut trade to some degree in recent years. Before 1999 six public agencies were the only importers of groundnut products; today, private firms are free to import groundnuts. However, while the government has committed to cap and reduce tradedistorting domestic subsidies as part of its WTO accession commitments, guaranteed prices and government procurement schemes remain in place. ${ }^{7}$ Furthermore, border protection remains high for processed groundnuts (30 percent). The tariff on raw groundnuts was only 15 percent in 2001, and many regions of China are natural exporters of groundnuts, making the tariff redundant. In-quota tariffs on groundnut oil (10 percent) and groundnut meal (5 percent) were much lower.

USDA attaché reports have repeatedly raised the issue of the uneven application of the Chinese value-added tax (VAT) on imported and domestic products. The VAT is significant, ranging from 13 to 17 percent, depending on the product, and there is ample room for tax evasion (USDA FASa, USDA FASb). The lack of uniformity in application prevents a more accurate measure of the impact. The quantitative policy analysis presented in the next section examines several cases with and without the VAT.

China's state trading imposes quantitative restrictions through quotas and licenses on groundnut oil imports, and it imposes tariff barriers on seeds, meal, and oil. These barriers create a wedge between domestic and world market prices. Domestic prices of most oils, including groundnut oil, are significantly higher than international market prices. Tariffs and rents on import licenses explain the price differentials. ${ }^{8}$

India. India removed most restrictions on domestic trade, storage, and export of groundnuts by 1998 and permitted trading in groundnut futures. However, import tariff levels remain very high for all three groundnut products. Moreover, in response to declines in prices, India has intensified its use of trade policy measures to protect its producers and processors. India is now the largest source of distortions in these product markets.
Tariffs on edible groundnuts and groundnut meal stood at 45 percent, while the tariff on groundnut oil was 35 percent in 2001 (see table 12.10). Since 2002 India has reversed its trade liberalization course on vegetable oil, increasing applied tariffs on groundnut oil to 65-75 percent in 2002-03 and 85 percent in 2003-04 (Gulati, Pursell, and Mullen, 2003; Pursell, 2003). The bound tariff is 100 percent.

Regulatory burdens increase domestic costs and prices. Producers are obligated to sell and purchase groundnuts only in the agricultural produce wholesale market. ${ }^{9}$ The "small-scale reservation" policy in groundnut processing sets limits on fixed assets in plant and machinery, preventing the domestic processing industry from realizing economies of scale.

\section{Groundnut Policies of Key African Exporters}

After decades of extensive intervention in the groundnut sector, to varying degrees African countries underwent market reforms in the 1980s under structural adjustment plans. One of the main objectives of market reforms was to eliminate direct and indirect taxation of farmers that had undermined production incentives in the 1970 s and early 1980s and led to underutilized processing capacities in many groundnut producing countries (Badiane and Kinteh 1994).

Reforms have been piecemeal and partial. Governments have generally withdrawn from input markets, making it difficult for producers to obtain certified seeds and fertilizer in countries such as The Gambia and Senegal, where there are market failures (in the credit market and elsewhere) and high transactions costs (Akobundu 1998). Governments have been reluctant to liberalize groundnut processing, for which privatization efforts started only recently (in The Gambia and Senegal). In The Gambia and Senegal producer prices are still set by the government.

African governments have traditionally used pricing policies as convenient levers to tax or subsidize farmers based on their industrial policies and political circumstances. ${ }^{10}$ Taxation of groundnut farmers was high in the 1970s but has been reversed since the early 1990s in most countries, while real world prices have trended downward (Badiane and Kinteh 1994). In The Gambia and Senegal the main 
rationale for state intervention in the groundnut sector has been to safeguard the viability of stateowned processing mills. Consequently, the share of the export price to groundnut farmers has consistently been less than 60 percent in these countries. This policy has been counterproductive for the state-owned enterprises, since farmers have bypassed large public processing companies, creating excess capacity and financial difficulties.

Trade policies vary widely among traditional groundnut exporters in Africa. Malawi and Senegal apply high tariffs on processed groundnuts to encourage domestic processing or oil production (table 12.11). In contrast, The Gambia and Nigeria have liberal trade policies, with no tariffs or export taxes. South Africa's tariff structure exhibits a slight escalation, with processed groundnuts subject to a tariff of 6 percent while unprocessed groundnuts enter duty free. In The Gambia and Senegal unofficial cross-border trade is significant, with farmers frequently crossing the border depending mainly on producer prices and domestic supply levels in the two countries. Groundnut oil imports face a 20 percent tariff in Malawi, Senegal, and South Africa.

African countries are facing difficulties meeting EU standards on aflatoxin and stricter product and quality standards. In The Gambia and Senegal groundnut varieties were originally selected for oil production, which can accommodate lower-quality seeds, and raw groundnuts. A seed variety in Malawi proved successful in producing better yields, but it lacked commercially viable characteristics. Groundnuts exported from most African countries are sold at a discount relative to the highquality groundnuts sold in the European Union.

African producers may be able to shift out of groundnut oil and upgrade the quality of their edible groundnuts. Unlike demand for groundnut oil and meal, demand for confectionery groundnut (the higher-quality edible groundnut) has been rising and is expected to continue to increase in the medium term. Confectionery groundnuts receive a price premium of as much as 100 percent over grades used for oil and meal. In Senegal 1 ton of first-grade confectionery groundnuts sells for $\$ 800-\$ 900$, equivalent to the price of groundnut oil. It takes three tons of unshelled groundnuts to produce 1 ton of oil. However, fob (free on board) prices of Gambian groundnuts are about $\$ 300$ for crushing, $\$ 450$ for birdfeed, and $\$ 600$ for edible

\section{TABLE 12.11 Tariffs on Groundnut Products in The Gambia, Malawi, Nigeria, Senegal, and South Africa (percent)}

\begin{tabular}{|c|c|}
\hline Country Product & Tariff 1999-2002 \\
\hline \multicolumn{2}{|l|}{ Gambia, The } \\
\hline Edible groundnuts & 0 \\
\hline Groundnut meal & 0 \\
\hline Groundnut oil (refined) & 0 \\
\hline \multicolumn{2}{|l|}{ Malawi } \\
\hline Raw edible groundnuts & 5 \\
\hline $\begin{array}{l}\text { Processed edible } \\
\text { groundnuts }\end{array}$ & 25 \\
\hline Groundnut meal & 0 \\
\hline Groundnut oil (refined) & 20 \\
\hline \multicolumn{2}{|l|}{ Nigeria } \\
\hline Edible groundnuts & 0 \\
\hline Groundnut meal & 0 \\
\hline Groundnut oil (refined) & 0 \\
\hline \multicolumn{2}{|l|}{ Senegal } \\
\hline Raw edible groundnuts & 5 \\
\hline $\begin{array}{l}\text { Processed edible } \\
\text { groundnuts }\end{array}$ & 20 \\
\hline Groundnut meal & 0 \\
\hline Groundnut oil (refined) & 20 \\
\hline \multicolumn{2}{|l|}{ South Africa } \\
\hline Raw edible groundnuts & 0 \\
\hline $\begin{array}{l}\text { Processed edible } \\
\text { groundnuts }\end{array}$ & 6 \\
\hline Groundnut meal & 0 \\
\hline Groundnut oil (refined) & 20 \\
\hline
\end{tabular}

Note: Raw edible groundnuts are raw, not roasted or cooked, in-shell or shelled groundnuts.

Processed groundnuts are bleached, preserved, or otherwise prepared groundnuts, including roasted and salted groundnuts and groundnut butter.

Source: World Trade Organization database.

groundnuts. Were The Gambia able to upgrade 50 percent of its 10,000 tons of exports from crushing to edible groundnuts, it would increase its revenues by $\$ 1.5$ million.

\section{Groundnut Trade Policies of High-Income Importers}

Despite a general pattern of tariff escalation, trade barriers are not a major obstacle to high-income groundnut importers: the European Union and Canada have a zero tariff for unprocessed groundnuts and low tariffs for processed groundnut for 
TABLE 12.12 Average Tariffs on Edible Unprocessed and Processed Groundnuts (percent)

\begin{tabular}{|c|c|c|c|c|c|c|}
\hline Importer & $\begin{array}{r}\text { Most-Favor } \\
\text { Tar } \\
\text { Unprocessed }\end{array}$ & $\begin{array}{l}\text { d-Nation } \\
\text { Processed }\end{array}$ & $\begin{array}{l}\text { Generalized } \\
\text { Preferences } \\
\text { Unprocessed }\end{array}$ & $\begin{array}{l}\text { ystem of } \\
\text { Tariffs } \\
\text { Processed }\end{array}$ & $\begin{array}{l}\text { Low-Income } \\
\text { Countrie } \\
\text { Unprocessed }\end{array}$ & $\begin{array}{l}\text { Peveloping- } \\
\text { Tariffs } \\
\text { Processed }\end{array}$ \\
\hline Canada & 0 & 4 & 0 & 4 & 0 & 3.2 \\
\hline European Union & 0 & 13 & 0 & 9 & 0 & 0 \\
\hline Japan & 3.7 & 19 & 3.7 & 19 & 3.7 & 15 \\
\hline Korea, Rep. of & 243 & 65 & 243 & 65 & 243 & 65 \\
\hline
\end{tabular}

Source: WTO.

generalized system of preferences (GSP) and lowincome developing countries (table 12.12). Assessment of market access in these countries must, however, take into account the strict quality standards.

In contrast to the European Union and Canada, Japan and the Republic of Korea have high tariff regimes for groundnuts. Japan applies a high tariff on processed groundnuts and offers a very limited preference margin of 4 percent for groundnut exports from low-income developing countries. Korea has very high tariffs on both raw and processed groundnuts, with tariffs on raw groundnuts of more than 200 percent. This high tariff may reflect the government's desire to stimulate production, which has plummeted since the mid 1980s. In contrast to edible groundnuts, groundnut oils and meal enter all of these high-income countries duty free.

\section{Impact of Groundnut Product Policy Reforms on World Prices, Trade Flows, and Welfare}

Several key findings emerge from the quantitative analysis of distortions in groundnut markets. (For a full description of the model, see Beghin and others 2003.) The main results obtained under the most plausible assumptions underlying the model are presented first, followed by sensitivity analysis testing the effects of U.S. policy and uncertainty about protection by China (VAT and protection of processed groundnuts).

\section{Policy Reform Scenarios}

Several scenarios are analyzed:

- Full multilateral trade liberalization for groundnuts, meal, and oil, with and without elimina- tion of the U.S. peanut program (FMTL\&US and FMTL)

- Multilateral trade liberalization of groundnuts, with and without elimination of the U.S. peanut program (GMTL\&US and GMTL)

- Full trade liberalization in the two largest and most distorted groundnut markets, China and India (CIFTL)

Summary results of these five scenarios are presented in tables 12.13 and 12.14. Detailed results for each scenario are presented in the longer report on the CD-ROM.

\section{Analysis Results}

In countries with high groundnut protection, the combined effect of the world price increase and elimination of their own protection is beneficial to final users of groundnuts, other things being equal. For countries with moderate or no protection before reform, tariff elimination and changes in the terms of trade result in an increase in domestic groundnut prices, handicapping groundnut users (consumers and crushers). A similar logic holds for groundnut oil and meal, for which the combined effect of world price increases and the elimination of tariffs has to be assessed. These substantial terms-of-trade effects have a significant impact on trade and welfare. Allocative efficiency gains in domestic markets can be offset by large price increases originating in postreform world markets.

In countries with high protection of groundnut oil or meal (such as India), tariff elimination, net of the world price hike, induces lower domestic prices and reduces margins on crushed groundnuts. As a result, the domestic excess supply of groundnuts 
TABLE 12.13 Welfare Effects of Policy Scenarios, 1999-2001 Average (millions of 1995 US\$)

\begin{tabular}{|l|r|r|r|r|r|}
\hline Country & FMTL\&US & FMTL & GMTL\&US & GMTL & CIFTL \\
\hline Argentina & 16.07 & 15.94 & 9.97 & 9.84 & 12.66 \\
EU-15 & -51.83 & -51.27 & -34.40 & -33.82 & -58.87 \\
China & 666.25 & 668.76 & 650.65 & 653.33 & 716.25 \\
India & 213.27 & 214.11 & 196.57 & 197.79 & 228.59 \\
Rest of the world & -126.69 & -127.06 & -4.21 & -4.86 & -71.06 \\
Canada & -5.94 & -5.87 & -4.88 & -4.81 & -4.59 \\
Mexico & -7.43 & -7.34 & -6.11 & -6.01 & -5.73 \\
Senegal & 41.03 & 40.96 & 21.93 & 21.86 & 21.39 \\
Nigeria & 15.93 & 15.77 & 7.22 & 7.07 & 13.45 \\
South Africa & 2.30 & 2.28 & 2.19 & 2.17 & 0.53 \\
Malawi & 7.45 & 7.45 & 7.60 & 7.61 & -1.06 \\
The Gambia & 0.43 & 0.42 & 0.24 & 0.24 & 0.36 \\
USA & 20.18 & 16.70 & 21.71 & 18.40 & 12.39 \\
Africa-5 total & 67.14 & 66.89 & 39.18 & 38.95 & 34.67 \\
Total & 791.01 & 790.87 & 868.48 & 868.79 & 864.32 \\
\hline
\end{tabular}

1. Denotes the aggregate of Senegal, Nigeria, South Africa, Malawi, and the Gambia. Source: USDA.

crushed into oil and meal decreases, increasing imports. In contrast, countries with moderate or no protection in their oil and meal markets face a net price increase for oil and meal after full trade liberalization. Their final consumption of these valueadded products decreases, and crushing increases, as the crush margin improves. Their excess supply of these products increase, and they increase exports.

The two full trade liberalization scenarios with and without the elimination of the U.S. farm policy (FMTL\&US and FMTL) induce strong price increases for all three products: 10 percent for groundnuts, 18 percent for groundnut meal, and 27 percent for groundnut oil (see table 12.13). The welfare impact of the FMTL\&US and FMTL reforms is influenced by the change in the groundnut oil price, which affects the crush margin. Crush margins narrow in the European Union and India, decreasing supply, but they may increase in China, The Gambia, Nigeria, Senegal, South Africa, and the United States.

Trade patterns change dramatically. China expands its exports of the three products. The large increase in the price of groundnut oil improves the crush margin, stimulating crushing in China. Higher prices for groundnut oil in world markets translate into larger exports. In India the lower crush margin reduces groundnut oil production and meal production; lower consumer prices for all groundnut products stimulate groundnut oil production and increase demand and eventually imports. African producers expand their exports of value-added products. Malawi and Senegal decrease their exports of groundnuts because of increased domestic use, while India experiences a trade reversal, becoming a large importer of groundnut oil and meal. Aggregate trade in groundnuts increases 16 percent, and trade in value-added products more than doubles.

The aggregate net welfare effects of FMTL\&US and FMTL amount to about $\$ 791$ million at 1995 prices in each scenario (see table 12.14). China and India experience the largest welfare gains - not surprisingly, since they have the two largest and most distorted groundnut product markets. China's welfare gains are about $\$ 666$ million, India's are about $\$ 213$ million. The "moderate" magnitude of global welfare gains first comes from offsets-some countries gain in aggregate whereas some others, chiefly the European Union-15, lose. For many countries other than China and India, individual net gains and losses are moderate, mostly because of the small size of the groundnut markets and their price-inelastic nature, which produces large transfers but small deadweight losses. Indeed, 
TABLE 12.14 Impact of Different Liberalization Scenarios on Groundnut Trade and Prices (percent)

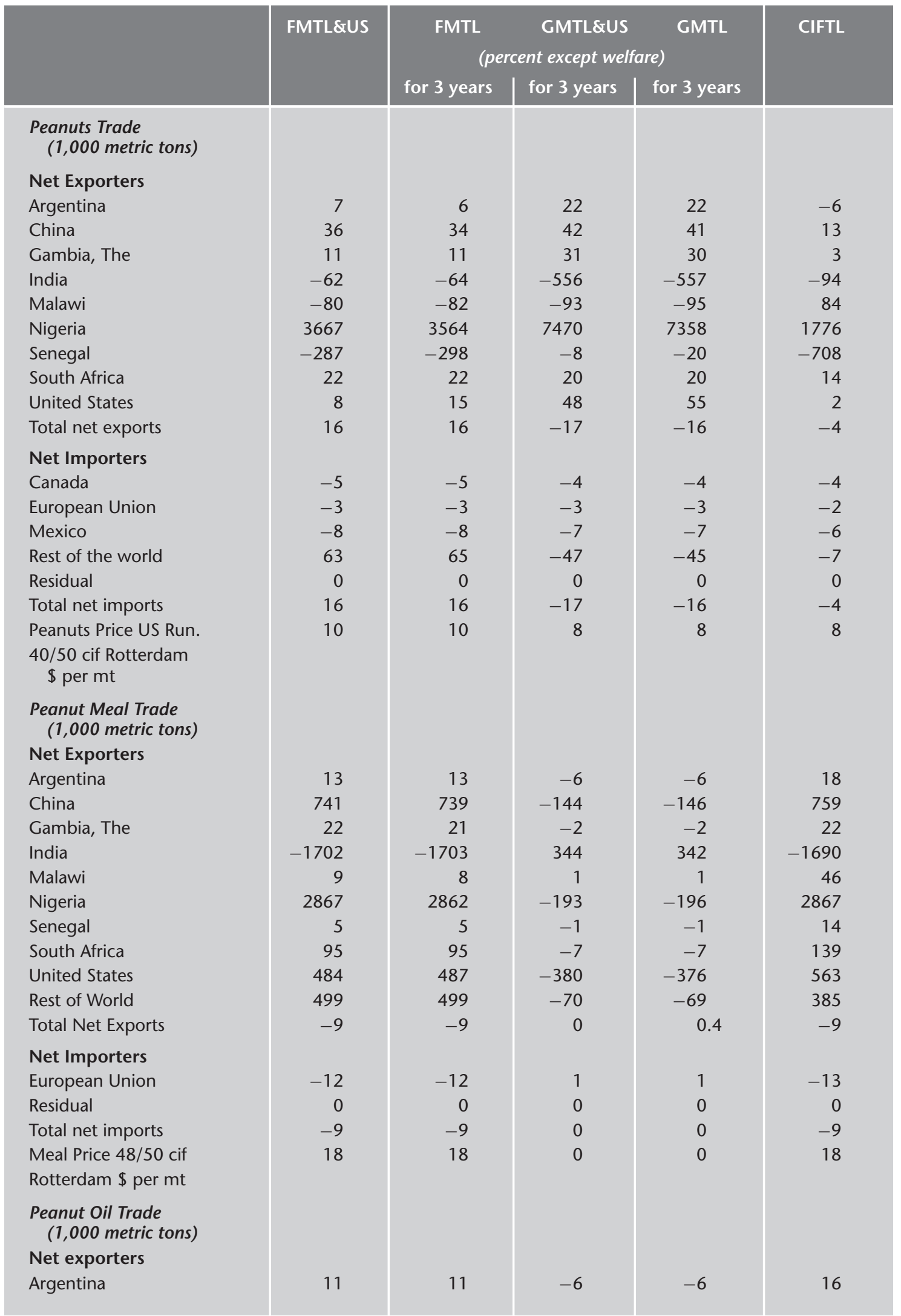


TABLE 12.14 (Continued)

\begin{tabular}{|c|c|c|c|c|c|}
\hline & FMTL\&US & $\begin{array}{c}\text { FMTL } \\
\text { for } 3 \text { years }\end{array}$ & $\begin{array}{l}\text { GMTL\&US } \\
\text { ent except wel } \\
\text { for } 3 \text { years }\end{array}$ & $\begin{array}{l}\text { GMTL } \\
\text { Ire) } \\
\text { for } 3 \text { years }\end{array}$ & CIFTL \\
\hline China & 3469 & 3459 & -705 & -713 & 3354 \\
\hline Gambia, The & 589 & 587 & -5 & -6 & 567 \\
\hline India & -24288 & -24304 & 4591 & 4558 & -24481 \\
\hline Malawi & 43 & 43 & 0 & 0 & 185 \\
\hline Nigeria & 123 & 123 & -6 & -6 & 120 \\
\hline Senegal & 5 & 5 & -1 & -1 & 19 \\
\hline South Africa & 49 & 49 & -4 & -4 & 224 \\
\hline United States & 288 & 290 & -194 & -192 & 326 \\
\hline Rest of world & 861 & 864 & -103 & -99 & 665 \\
\hline Total net exports & -6 & -6 & 0 & 0 & -8 \\
\hline \multicolumn{6}{|l|}{ Net importers } \\
\hline European Union & -9 & -9 & 0 & 0 & -12 \\
\hline Residual & 0 & 0 & 0 & 0 & 0 \\
\hline Total net imports & -6 & -6 & 0 & 0 & -8 \\
\hline $\begin{array}{l}\text { Peanut Oil Price cif } \\
\text { Rotterdam \$ per mt }\end{array}$ & 27 & 27 & 0 & 0 & 26 \\
\hline welfare(million dollars) & 791 & 791 & 868 & 869 & 864 \\
\hline Argentina & 16.07 & 15.94 & 9.97 & 9.84 & 12.66 \\
\hline EU-15 & -51.83 & -51.27 & -34.40 & -33.82 & -58.87 \\
\hline China & 666.25 & 668.76 & 650.65 & 653.33 & 716.25 \\
\hline India & 213.27 & 214.11 & 196.57 & 197.79 & 228.59 \\
\hline Rest of world & -126.69 & -127.06 & -4.21 & -4.86 & -71.06 \\
\hline Canada & -5.94 & -5.87 & -4.88 & -4.81 & -4.59 \\
\hline Mexico & -7.43 & -7.34 & -6.11 & -6.01 & -5.73 \\
\hline Senegal & 41.03 & 40.96 & 21.93 & 21.86 & 21.39 \\
\hline Nigeria & 15.93 & 15.77 & 7.22 & 7.07 & 13.45 \\
\hline South Africa & 2.30 & 2.28 & 2.19 & 2.17 & 0.53 \\
\hline Malawi & 7.45 & 7.45 & 7.60 & 7.61 & -1.06 \\
\hline Gambia, The & 0.43 & 0.42 & 0.24 & 0.24 & 0.36 \\
\hline United States & 20.18 & 16.70 & 21.71 & 18.40 & 12.39 \\
\hline Africa-5 total ${ }^{a}$ & 67.14 & 66.89 & 39.18 & 38.95 & 34.67 \\
\hline Total & 791.01 & 790.87 & 868.48 & 868.79 & 864.32 \\
\hline
\end{tabular}

Note: Table totals are average changes for three years totaled in each column. Results are percentage changes from the baseline. Baseline and simulations were run for three years (1999-2001) and averaged. a. Totals are three-year averages.

Source: computed by the authors

a. Denotes the aggregate of Senegal, Nigeria, South Africa, Malawi, and The Gambia.

substantial offsetting transfers occur between consumers, crushers, and producers.

Price effects induced by the reforms have a similar impact large welfare transfer (rectangles) and small net welfare effects (triangles), even in countries with undistorted markets. In Nigeria, for example, following full multilateral trade liberalization without elimination of the U.S. peanut pro- gram, groundnut producers gain $\$ 34$ million in quasi-rents, consumers experience welfare losses of $\$ 65$ million (because of higher oil and processed groundnut prices), crushers gain $\$ 51$ million, and meal users (feed users) lose about $\$ 3$ million. In aggregate the country is better off by $\$ 16$ million.

Under multilateral trade liberalization for all three products, elimination of the U.S. program 
affects trade flows, terms of trade, and welfare. The strong price effects of trade liberalization invalidate the price floor established by the U.S. loan rate. The only remaining production-distorting element is the fixed payment (fully coupled to production in the model), which is small. Results under both scenarios (full trade liberalization with and without elimination of the U.S. peanut program) are qualitatively identical, except for the United States, which experiences additional welfare gains of $\$ 3.5$ million (gains to U.S. taxpayers net of losses by U.S. producers) by eliminating its domestic distortions.

The world price impacts of the FMTL scenario are identical to those of FMTL\&US (a 10 percent increase for groundnuts, an 18 percent increase for meal, and a 27 percent increase for groundnut oil). Trade flows are barely affected by the elimination of the U.S. domestic program under free trade. U.S. groundnut exports are about 15,000 metric tons lower in the FMTL\&US scenario than in the FMTL scenario. Given that the parameterization of U.S. farm policy assumes full coupling to production for payments received by producers, the assessment provides an upper bound on the effect of the current U.S. peanut program. ${ }^{11}$

Many agricultural negotiations during the Doha Round of the WTO revolve around narrow issues of substantial importance to developing countries. Hence it is useful to assess what a narrow agricultural liberalization encompassing the value-added products of groundnut oil and meal would achieve relative to full trade liberalization.

The GMTL\&US and GMTL scenarios consider these reforms and their impacts. Much is achieved by groundnut trade liberalization alone, but with a large second-best component, since distortions are present in the value-added markets. In these groundnut liberalization scenarios, the prices of meal and oil are little affected, and crush margins are driven primarily by changes in groundnut prices. Margins improve in India but deteriorate in countries with limited groundnut distortions.

Consumer welfare implications are also different in these trade scenarios. In highly protected groundnut oil markets, prices are higher under the groundnut trade (GMTL) scenarios than they are under all-product trade liberalization (FMTL scenarios). In countries with no oil distortions, prices remain roughly at their baseline level, and consumers do better under the groundnut trade liberalization than under the full liberalization scenarios. The rest of the world fares much better under the groundnut trade liberalization scenarios than under the full liberalization scenarios. In contrast, African economies do much better under the full liberalization scenarios than with groundnut trade liberalization reforms. The potential welfare gains for Africa-5 (The Gambia, Malawi, Nigeria, Senegal, and South Africa) nearly double by moving from groundnut trade liberalization to full liberalization scenarios.

If China and India liberalized alone (the CIFTL scenario), the qualitative results of the full liberalization scenarios hold. What is striking in this last scenario is the importance of India's - and to a lesser extent China's-distortions and market size on welfare, trade, and price effects. As suggested by table 12.13, FMTL really hinges on the elimination of distortions in India and China. With liberalization in India and China, world prices would rise 8 percent for groundnuts, 18 percent for meal, and 26 percent for oil. The major welfare differences occur in the rest of the world, where consumers are worse off than they would be under the multilateral groundnut trade liberalization scenario, since groundnut oil prices are higher. Africa-5 improves its lot in aggregate but by less than it would under the full liberalization scenario, since groundnut prices are lower and distortions within Africa-5 remain in place.

Two key assumptions in the model — the prevailing groundnut market price in the U.S. market and the level of protection of the groundnut market in China-were investigated. The model was calibrated on 2002-03 U.S. prices (\$389 per metric ton) to see if the new U.S. policy under the 2002 Farm Bill would have had a stronger impact on the world market under lower prevailing prices (farm prices in the United States were 25 percent lower in 2002-03 than in 2001-02). The loan rate, countercyclical payments, and fixed payments were eliminated (countercyclical payments and fixed payments are assumed to be fully coupled to provide an upper bound on the effect of the U.S. program), while all distortions in all other countries were retained. The price floor provided by the loan rate is effective under the lower 2002-03 farm price.

U.S. output decreases 7 percent under the new prices, and U.S. exports decrease 52 percent, inducing a 0.9 percent increase in the world price of groundnuts and negligible price impacts in the other markets. The aggregate net welfare effect is 
negligible and negative. Higher world prices exacerbate distortions in other markets or increase import costs in net importing countries. The United States gains about $\$ 22$ million (program cost savings net of producer loss).

The same change was also tested with all other distortions removed in all countries (FMTL\&US scenario). In this scenario the world price of groundnuts was 0.5 percent higher than under free trade plus the 2002 U.S. Farm Bill. The results suggest that removing the 2002 Farm Bill incentives in a free trade world would decrease U.S. production about 4 percent and exports about 31 percent. The aggregate welfare gains vary by less than $\$ 1$ million. Hence the conclusion that the new U.S. groundnut policy is more benign than its predecessor remains unaltered under much lower prices.

The sensitivity analysis on China's protection structure is more pivotal to the conclusions reached, especially the protection of the groundnut sector. Protection of groundnut producers is now assumed to be 15 percent (the tariff is redundant in the original model). Without assistance the Chinese farm sector is no longer assumed to be a net exporter. Under this new assumption and following full trade liberalization (FMTL\&US), China becomes a net importer of groundnuts, because demand for edible and crushed groundnuts increases. China's welfare gains are \$1,029 million; aggregate welfare gains are $\$ 1,160$ million. World prices increase 18 percent for groundnuts, 19 percent for meal, and 29 percent for oil.

A second sensitivity analysis examines the effect of providing baseline protection of processed groundnuts with a 15 percent ad valorem tariff (the original tariff was 30 percent and the VAT was 17 percent). Under this assumption welfare gains from FMTL are only $\$ 266$ million in China, and aggregate gains are just $\$ 388$ million. The world price of groundnuts increases 9 percent in this modified scenario, down from 10 percent under the original run. The major change in welfare occurs in China, because Chinese consumers gain much less from trade liberalization relative to the initial situation.

\section{Conclusions and Policy Implications}

The groundnut market has historically been distorted by heavy government intervention in both industrial and developing countries. In the United
States the 2002 Farm Bill eliminated some unsustainable features of earlier policies, but it introduced new distortions that have some limited potential to depress world market prices and subsidize U.S. groundnut exports. India and China have succeeded in stimulating production and exports, capturing a growing share of the international market. In India these gains have been artificial, because the groundnut industry relies on heavy protection. In contrast, in Sub-Saharan Africa and Argentina, government intervention has hurt the sector.

Unlike U.S. policy for cotton, dairy, rice, and sugar, the current U.S. domestic peanut program is now largely a domestic support program with some distortive impact. The scenario analysis suggests that developing countries would gain little by trying to negotiate further U.S. groundnut policy reform, as these changes would prove ineffective unless groundnut prices fell to very low levels. Only then would the countercyclical U.S. policy further destabilize world prices, sending the wrong market signal to U.S. producers. Under prevailing market conditions, U.S. producers would actually benefit from multilateral trade liberalization in groundnut product markets. Hence it would be rational for the United States to support foreign groundnut producers in their attempt to liberalize. As a bloc most OECD (Organisation for Economic Cooperation and Development) countries would experience welfare losses after trade liberalization, with moderate gains in the United States offset by losses in Canada, Mexico, and the European Union15. Mexico, Canada, and the European Union-15 would lose from trade liberalization because there are few distortions in these markets, so consumers would be penalized by price increases for groundnut products.

Elimination of trade distortions by the two largest developing economies, India and China, is essential. The size of their markets-and the huge distortions in India-substantially depress world prices of the three globally traded groundnut products. Following elimination of these distortions, net buyers of these products would be worse off, but most Sub-Saharan African countries that export groundnuts would gain.

Full trade liberalization would increase world market prices about 10 percent for groundnuts, 18 percent for groundnut meal, and 27 percent for 
groundnut oil. Trade in groundnuts would increase 16 percent, and trade in oil and meal would more than double.

Although the net world welfare effects of liberalizing markets in the United States, China, and India are moderate, they remain significant for small agrarian economies in Sub-Saharan Africa. Liberalization would thus produce welfare gains in the countries in which they are most needed.

The simulations show that liberalization of the value-added markets is essential to achieve larger welfare gains in African countries. Although the bulk of the world welfare gains occur with groundnut trade liberalization, elimination of distortions in value-added markets doubles net welfare gains in Africa by yielding larger profits to producers and exporters of groundnuts and groundnut oil. African countries modeled in the trade liberalization analysis would experience aggregate welfare gains of $\$ 67$ million, with Senegal and Nigeria reaping most of these gains. Groundnut and groundnut oil consumers in Africa tend to be urban, whereas groundnut production generates income in rural areas as a cash crop. African groundnut producers modeled in the analysis gain $\$ 50$ million-\$150 million of farm income, depending on the assumptions underlying the model. These figures are significant for small African economies and represent an important opportunity to expand rural development in these areas. In the scenarios tested, the rest of the world would fare worse under full trade liberalization, because consumers are required to pay higher groundnut product prices. Groundnuts are not without substitutes, however, and the price increase may induce increases in demand for other oils.

Recent changes present both challenges and opportunities for major countries in the market. The United States is likely to continue to dominate the high end of the international confectionery market under its new peanut program. Argentina and China have established strong groundnut sectors that can compete favorably under free market conditions. Chinese exports played a stabilizing role in world markets in the 1990s.

All developing countries except Argentina face the challenge of meeting the quality requirements of the expanding confectionery markets. This is particularly so for African countries, which are missing out on the opportunities and rewards created by the expansion of the edible groundnut exports market because of inadequate quality.

\section{Notes}

1. Groundnuts are also known as peanuts, earthnuts, goobers, pinders, and Manila nuts. The groundnut plant is a hairy, tap-rooted, annual legume that measures 1-1.5 feet in height.

2. Groundnut oil is an excellent cooking oil, with a high smoke point and neutral flavor and odor. Groundnut meal is used as animal feed.

3. Any grower in the group is eligible to farm a certain number of acres of land. Farmers who use the land are obligated, however, to pay agricultural tax in kind and sell a certain amount of their products to the state government at regulated prices.

4. Export markets reflect relatively high-quality premiums and discounts. Prices of U.S. groundnuts set a ceiling for international prices, because the quality is high. Edible U.S. groundnuts commanded a 40 percent premium on world markets over shelled Chinese groundnuts in 2000 (FAO 2002).

5. In 1998 the EU harmonized country regulations on the maximum permissible level of aflatoxin, setting levels at the lowest possible level (0.002 milligrams for B1 type aflatoxin for edible groundnuts). Aflatoxin is a cancer-causing chemical produced by species of aspergillus molds that can contaminate groundnuts. The spores of these molds, present anywhere in the air and the soil, require specific temperature, moisture, and nutrient substrates to germinate. Aflatoxin contamination of groundnuts can occur during cultivation in the field, as well as during harvesting, postharvesting, storage, or processing. While aflatoxin disappears with crushing, it remains in edible groundnuts and groundnut meal. Technical processes exist to reduce aflatoxin contamination (with ammoniac, for example, which Senegal uses on groundnut meal), but the best method is to improve farm practices through use of best-quality and resistant seeds, proper management of farms, and appropriate storage to avoid exposure to high temperature and humidity. See chapter 6 in this volume for a discussion of food safety and agricultural health standards.

6. The levels of quota and tariff for the period after 2003 are currently under negotiation.

7. According to the FAO (Food and Agriculture Organization), these policies provide little incentive to expand production due to unattractive administrative price levels and greater involvement of the private sector in marketing operations. Data on the magnitude of domestic support are not available.

8. The international price of groundnut oil in Hong Kong (China) was $\$ 728$ a ton in 1998 , and the wholesale price in China was 67.8 percent higher (Fang and Beghin 2002).

9. This regulation imposes a significant burden on farmers and processors. Even if they are located very close to one another, they have to travel to the wholesale market and pay an "agent commission" and other marketing fees before the transaction is processed.

10. Taxation of producers was direct (that is, marketing boards or similar agencies captured the rent, equal to the difference between the net world price and the producer price) or indirect (through appreciation of the real exchange rate). This taxation was generally mitigated by input subsidies and border protection.

11. Eliminating U.S. distortions under existing trade distortions produces a 0.13 percent increase in the world price of 
groundnuts and virtually no increase in world cake and oil prices. U.S. groundnut exports decrease by 10 percent, or about 20,000 metric tons a year. Thus in contrast to the effect of U.S. subsidies on rice, cotton, and sugar, the impact of the current U.S. farm program on the world price of and trade in groundnuts is negligible.

\section{References}

Akobundu E. 1998. Farm-Household Analysis of Policies Affecting Groundnut Production in Senegal. MS Thesis, Virginia Polytechnic and State University.

Badiane, O., and Kinteh, S. 1994. "Trade Pessimism and Regionalism in African Countries: The Case of Groundnut Exporters.” IFPRI Research Report 97. International Food Policy Research Institute, Washington, D.C.

Beghin, J., N. Diop, H. Matthey, and M. Sewadeh. 2003. “The Impact of Groundnut Trade Liberalization: Implication for the Doha Round." Presented at the 2003 American Agricultural Economics Association Annual Meeting, July 27-30, Montreal.

Chen, Changping, Stanley M. Fletcher, Ping Zhang, and Dale H. Carley. 1997. "Competitiveness in Peanuts: United States versus China.” Research Bulletin 430. University of Georgia, Georgia Agricultural Experiment Station.

Colby, W. H., F. W. Crook, and S. Webb. 1992. Agricultural Statistics of the People's Republic of China, 1949-1990. SB-844, United States Department of Agriculture, Economic Research Service, December.

Diop, N., J. Beghin, and M. Sewadeh. 2004. "Groundnut Policies, Global Trade Dynamics and the Impact of Trade Liberalization," World Bank Policy Research Working Paper 322. Washington, D.C.

Gulati, A., G. Pursell, and K. Mullen. 2003. "Indian Agriculture since the Reforms: Performance, Policy Environment, and Incentives." World Bank, Washington, D.C.

Fang C., and J. Beghin. 2002. "Urban Demand for Edible Oils and Fats in China: Evidence from Household Survey Data." Journal of Comparative Economics 30(4): 732-53.
FAO (Food and Agriculture Organization of the United Nations) 2002. FAO Yearbook. Trade. Rome.

Fletcher, S. M. 2001. "Peanuts: Responding to Opportunities and Challenges from an Intertwined Trade and Domestic Policies.” University of Georgia, National Center for Peanut Competitiveness, Griffin, Ga.

Fletcher, S. M., and C. L. Revoredo. 2003. "Does the United States Need the Groundnut Tariff Rate Quota Under the 2002 U.S. Farm Act?" Paper presented at the International Conference on Agricultural Policy and the WTO: Where Are We Heading, June 23-26, Capri, Italy.

Hart, C. and B. Babcock. 2002. "U.S. Farm Policy and the WTO: How Do They Match Up?” The Estey Centre Journal of International Law and Trade Policy 3:119-39.

Pursell, G. 2003. Private e-mail correspondence on India's groundnut protection, September.

Revoredo, C. L., and S. Fletcher. 2002a. "The U.S. 2002 Farm Act and the Effects on U.S. Groundnut Exports." University of Georgia, Griffin, Ga.

2002b. "World Peanut Market: An Overview of the Last 30 Years." University of Georgia, Griffin, Ga.

Skinner, R. 1999. "Issues Facing the United States: Peanut Industry during the Seattle Round of the World Trade Organization." U.S. Department of Agriculture, Economic Research Service, Washington, D.C.

USDA FAS (U.S. Department of Agriculture, Foreign Agriculture Service). GAIN Reports, various years a. "China, People's Republic of. Oilseeds and Products. Oilseeds Update.” Washington, D.C.

- Various years b. "China, People’s Republic of. Oilseeds and Products. Annual." Washington, D.C.

Wescott, P. C., C. E. Young, and J. M. Price. 2002. “The 2002 Farm Act Provisions and Implications for Commodity Markets.” Agriculture Information Bulletin Number 778. U.S. Department of Agriculture, Economic Research Service, Washington, D.C. 
Iowa State University does not discriminate on the basis of race, color, age, religion, national origin, sexual orientation, gender identity, sex, marital status, disability, or status as a U.S. veteran. Inquiries can be directed to the Director of Equal Opportunity and Diversity, 3680 Beardshear Hall, (515) 294-7612. 